\title{
Synthesis, Characterization, Investigation of AChE Activities and Molecular Docking Studies of New Schiff Bases Based on Substitute Salicyl Aldehyde
}

\section{Subtitüe Salisil Aldehit Temelli Yeni Schiff Bazlarının Sentezi, Karakterizasyonu, AChE Aktivitelerinin İncelenmesi ve Moleküler Yerleştirme Çalışmaları}

\author{
İrfan Şahin \\ Department of Chemistry, Faculty of Art and Sciences, Kahramanmaras Sutcu Imam University, Kahramanmaras, TURKEY
}

ABSTRACT

| $n$ this study, two new Schiff base compounds (4 and 5) based on substituted salicyl aldehyde were synthesized. The structures of the synthesized compounds were determined by FT-IR and ${ }^{1} \mathrm{H}\left({ }^{13} \mathrm{C}\right)$ NMR spectroscopies. The AChE inhibition activities of the compounds were investigated. According to the results obtained, the activities of compounds 4 (IC I $_{50}: 1.396$ $\pm 0.35 \mu \mathrm{M})$ and $5\left(\mathrm{IC}_{50}: 0.795 \pm 0.47 \mu \mathrm{M}\right)$ were found to be significantly effective than Tacrin (TAC) (IC $\left.{ }_{50}: 166.10 \pm 17.53 \mu \mathrm{M}\right)$ (currently used drug). The interaction types and binding energies of compound 5, which has higher activity, were investigated by molecular docking studies.

Key Words

Schiff base, AChE inhibition activity, molecular docking.

Bu,

u çalışmada, substitute salisil aldehit temelli yeni Schiff bazları (4 ve 5) sentezlendi. Sentezlenen bileşiklerin yapıları FTIR, ${ }^{1} \mathrm{H}\left({ }^{13} \mathrm{C}\right)$ NMR spektroskopileri ile aydınlatıldı. Bileşiklerin AChE inhibisyon aktiviteleri araştırıldı. Elde edilen sonuçlara göre $4\left(I C_{50}: 1.396 \pm 0.35 \mu \mathrm{M}\right)$ ve $5\left({ }^{2} C_{50}: 0.795 \pm 0.47 \mu \mathrm{M}\right)$ bileşiklerinin aktiviteleri standart olarak kullanılan Tacrinden (TAC) $\left(\mathrm{IC}_{50}: 166.10 \pm 17.53 \mu \mathrm{M}\right)$ çok daha yüksek inhibisyon aktivitesi sergilemiştir. Yüksek aktiviteye sahip olan bileşik $5^{\prime}$ in moleküler yerlestirme çalışmaları ile etkileşim türleri ve bağlanma enerjileri hesaplanmıştır.

\section{Anahtar Kelimeler}

Schiff bazı, AChE inhibisyon aktivitesi, moleküler yerleștirme.

Article History: Received: Nov 12, 2021; Revised: Jan 6, 2022; Accepted: Jan 28, 2022; Available Online: Feb 28, 2022 DOI: https://doi.org/10.15671/hibc.1020606

Correspondence to: I. Şahin, Department of Chemistry, Kahramanmaras Sutcu Imam University, Kahramanmaras, Turkey. E-Mail: irfansahin@ksu.edu.tr 


\section{INTRODUCTION}

chiff bases are also known as imines formed by the $\checkmark$ reaction condensation of primary amines with aldehydes or ketones [1]. The reaction is shown in Fig 1.

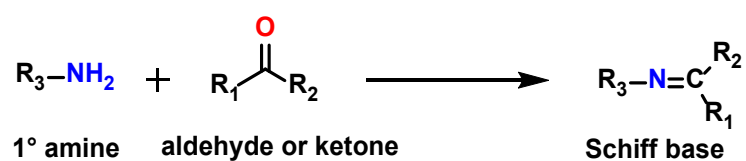

Figure 1. ${ }^{1} \mathrm{H}$ NMR spectrum of pyrazole $\mathbf{4 b}$.

The widely used Schiff bases constitute an important class of organic compounds. Schiff bases has various applications including paint, catalyst and organic intermediates etc. Moreover, Schiff bases have shown to exhibit various biological activities anti-diabetic, antibacterial, Alzheimer's, antimalarial, antifungal, anti-inflammatory, antipyretic, antiviral and antiproliferative [1-7]. Imine groups $(-\mathrm{CH}=\mathrm{N}-)$ are found in the structure of many natural compounds and the effect of this group is very important for biological activities [8].Therefore, the number of publications on Schiff bases in the fields of chemistry, pharmacy, biochemistry and industry is quite high and continues to increase [9].

Alzheimer's disease (AD) is a neurodegenerative disease that occurs as the most common cause of dementia in the elderly and causes a decrease in thinking, unders- tanding and cognitive skills [10,11]. In 2021, there are 2.3 million people over the age of 85 with Alzheimer's disease, making up $36 \%$ of all people with Alzheimer's worldwide. It is thought that this number will reach 6.7 million people over the age of 85 by 2060, and this value will correspond to nearly half of all people over the age of 65 with dementia [12]. AD begins with the appearance of plaques and tangles that kill neurons in brain tissue and in some parts of the brain [13]. Neurons cannot renew themselves, so acetylcholine (ACh) levels produced by neurons decrease [11]. ACh is necessary for the proper development of the brain, but the decrease in ACh level in dementia patients causes problems such as thinking, remembering and reasoning [14]. General symptoms seen in 65-year-old patients initially result in short-term memory loss, and in advanced levels, organ failure and death $[15,16]$. Currently, there is no effective method for the treatment of Alzheimer's, but inhibiting ACh degradation by blocking AChE has proven to be effective in reducing the progression of the disease [17].

It has been reported in the literature that Schiff bases show high activity as AChE inhibitors [18-20]. In this work, we are reporting the synthesis of new Schiff bases based on substituted salicylaldehyde and acetylcholinesterase (AChE) inhibitory activities and molecular docking studies.
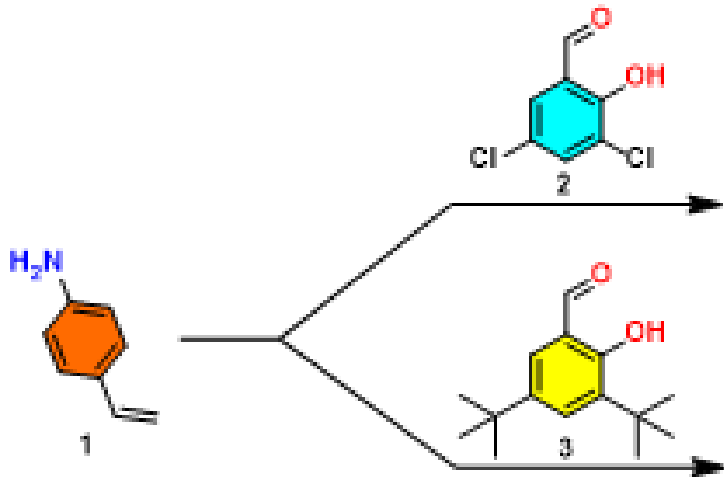

1
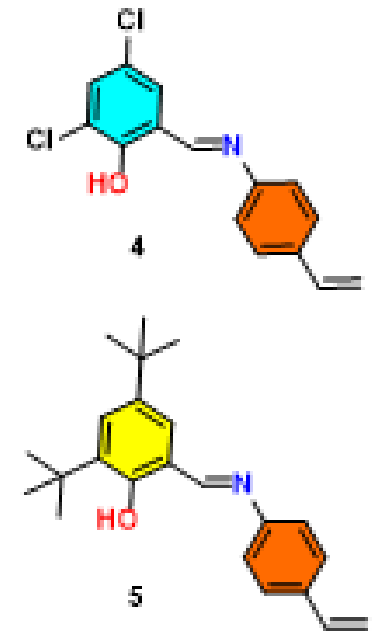

Figure 2. Synthesis scheme of compounds 4 and 5 . 


\section{MATERIALS and METHODS}

\section{Materials and Instrumentation}

All reagents and solvents were purchased from commercial companies and were of reagent-grade purity (Aldrich or Merck). A Perkin-Elmer FT-IR spectrometer (Spectrum 400) equipped with an ATR was used to record infrared spectra. ${ }^{1} \mathrm{H}\left({ }^{13} \mathrm{C}\right)$ NMR spectra were obtained on a Bruker $400 \mathrm{MHz}$ equipment and TMS was utilized as an internal standard. In $\mathrm{CDCl}_{3}$ solvent, the compounds ${ }^{1} \mathrm{H}\left({ }^{13} \mathrm{C}\right)$ NMR spectra were examined. The Hitachi $\mathrm{U} 3900 \mathrm{H}$ Spectrophotometer was used to measure the inhibitory activity of AChE.

\section{Synthesis Method of Compounds (4 and 5)}

All of the substances were made using a method described in the literature [21]. $1 \mathrm{mmol}$ of aldehyde compound ( 2 or 3 ) was dissolved in $20 \mathrm{~mL}$ of methanol. $1 \mathrm{mmol}$ of 4-vinylaniline (1) was added and refluxed for 6 hours. The progress of the reaction was checked by TLC. After the reaction was complete, the resulting solids were filtered and dried. Fig. 2 illustrated the general synthesis method.

(E)-2,4-dichloro-6-(((4-vinylphenyl)imino)methyl)phenol (4): m.p.: $125-126^{\circ} \mathrm{C}$. Yield: $95 \%$. Colour: Dark orange solid. FTIR (U, $\left.\mathrm{cm}^{-1}\right)$ : 3393, 3077, 2913, 2852, 1613, 1446, 1237, 1177, 864. ${ }^{1} \mathrm{H}$ NMR (400 MHz, $\left.\mathrm{CDCl}_{3}\right): \delta 14.34(\mathrm{~s}$, $1 \mathrm{H}), 8.62(\mathrm{~s}, 1 \mathrm{H}), 7.54-7.48(\mathrm{~m}, 2 \mathrm{H}), 7.35-7.29(\mathrm{~m}, 4 \mathrm{H})$ $6.76(\mathrm{dd}, \mathrm{J}=17.6,10.9 \mathrm{~Hz}, 1 \mathrm{H}), 5.82\left(\mathrm{~d}, \mathrm{~J}_{\text {trans }}=17.6 \mathrm{~Hz}, 1 \mathrm{H}\right)$, $5.34\left(\mathrm{~d}, \mathrm{~J}_{\text {cis }}=10.9 \mathrm{~Hz}, 1 \mathrm{H}\right) \cdot{ }^{13} \mathrm{C} \mathrm{NMR}\left(100 \mathrm{MHz} \mathrm{CDCl}_{3}\right): \delta$ $159.70,156.09,146.07,137.48,135.83,132.71,129.70$ $127.45,123.38,122.91,121.47,120.25,114.80$.

(E)-2,4-di-tert-butyl-6-(((4-vinylphenyl)imino)methyl) phenol (5): m.p.: $115-116{ }^{\circ} \mathrm{C}$. Yield: $93 \%$. Colour: Light yellow solid. FTIR $\left(\mathrm{U}, \mathrm{cm}^{-1}\right)$ : 3081, 2950, 2905, 2864 $1617,1439,1249,1166,871 .{ }^{1} \mathrm{H}$ NMR $\left(400 \mathrm{MHz}, \mathrm{CDCl}_{3}\right): \delta$ $13.74(\mathrm{~s}, 1 \mathrm{H}), 8.68(\mathrm{~s}, 1 \mathrm{H}), 7.51-7.46(\mathrm{~m}, 3 \mathrm{H}), 7.32-7.24(\mathrm{~m}$, $3 \mathrm{H}), 6.76(\mathrm{dd}, \mathrm{J}=17.6,10.9 \mathrm{~Hz}, 1 \mathrm{H}), 5.79\left(\mathrm{~d}, \mathrm{~J}_{\text {trans }}=17.6\right.$ $\mathrm{Hz}, 1 \mathrm{H}), 5.29$ (d, $\left.\mathrm{J}_{\text {cis }}=10.9 \mathrm{~Hz}, 1 \mathrm{H}\right), 1.51(\mathrm{~s}, 9 \mathrm{H}), 1.36$ (s, 9H). ${ }^{13} \mathrm{C}$ NMR $\left(100 \mathrm{MHz}, \mathrm{CDCl}_{3}\right): \delta 163.32,158.31,148.07$, $140.62,137.01,136.15,136.08,128.07,127.22,126.82$, $121.39,118.34,113.83,35.12,34.21,31.49,29.45$.

\section{Pharmalogical-Biological Studies \\ Acetylcholinesterase (AChE) inhibition studies}

The inhibition activities of the test compounds on the cholinergic enzyme AChE were determined using the Ellman method [22]. The enzyme solution was prepared as 0.22 units $/ \mathrm{mL}$. Tacrin and test compounds were studied at concentrations of 1.36-0.085 $\mu \mathrm{M}$. Standard Tacrin (TAC) and test compounds ( 4 and 5 ) were dissolved in a water-DMSO mixture (9:1). $100 \mu \mathrm{L}$ of phosphate buffer ( $\mathrm{pH}: 6.7)$ was added to each well of 96 well-plates. Different concentrations of test compounds $(20 \mu \mathrm{L})$ and $\mathrm{AChE}$ (20 $\mathrm{\mu L} /$ well) were added to it and incubated at $25^{\circ} \mathrm{C}$ for 10 minutes. The chromatographic reagent was started by adding 5,5-dithio-bis(2-nitrobenzoic acid) (DTNB) $(3 \mathrm{mM}, 50 \mu \mathrm{L} /$ well) and the substrates acetylthiocholine iodine (ATCI) $(3 \mathrm{mM}, 50 \mu \mathrm{L} /$ well) to the enzyme-inhibitor mixture. Yellow anion formation was recorded at 412 $\mathrm{nm}$ for 10 minutes. An identical solution of the enzyme was prepared without compounds, designated as control. Control and inhibitor readings were corrected with a blank read. The study was repeated three times. The concentrations of the samples that inhibited the degradation of the substrate (acetylcholine) by $50 \%\left(\mathrm{IC}_{50}\right)$ were determined by linear regression analysis between percent inhibition and sample concentration using the excel program $[23,24]$.

\section{RESULTS and DISCUSSION}

In the content of this work, new two imine compounds were prepared in high yield and purity. These compounds were characterized by common spectroscopic methods. In the FT-IR spectra of the compounds (4 and 5), characteristic vibrational bands belonging to the aliphatic-CH group were observed between $v 3081$ and $2852 \mathrm{~cm}^{-1}$. The characteristic stretchings of the imine groups of the synthesized compounds (4 and 5) were detected at 1613 and $1617 \mathrm{~cm}^{-1}$, respectively. Characteristic vibrational peaks belonging to the vinyl group were observed for compound 4 at v 1662 and $864 \mathrm{~cm}^{-1}$, and for compound 5 at $\vee 1650$ and $871 \mathrm{~cm}^{-1}$. The existence of characteristic bands in the compounds FT-IR spectra validates their structures.

In the ${ }^{1} \mathrm{H}$ NMR spectrum of compound 5 , the 18 protons belonging to the t-butyl groups resonated as two separate singlets at $\delta 1.36$ and $\delta 1.51 \mathrm{ppm}$. The cis-proton in the vinyl group was observed as a doublet at $\delta 5.29$ ppm, and the trans- $\mathrm{H}$ at $\delta 5.79 \mathrm{ppm}$. The vinyl group proton $(-\mathrm{CH}=\mathrm{C})$ resonated at $\delta 6.76 \mathrm{ppm}$ as a doublet of the doublet. The aromatic $\mathrm{C}-\mathrm{H}$ protons were observed in the range of $\delta$ 7.51-7.46 ppm and $\delta$ 7.32-7.24 ppm as overlapped multiplet peaks. The singlet peak observed at $\delta 8.68 \mathrm{ppm}$ belongs to the imine proton, and the peak observed at $\delta 13.74$ ppm belongs to the hydroxyl group. 

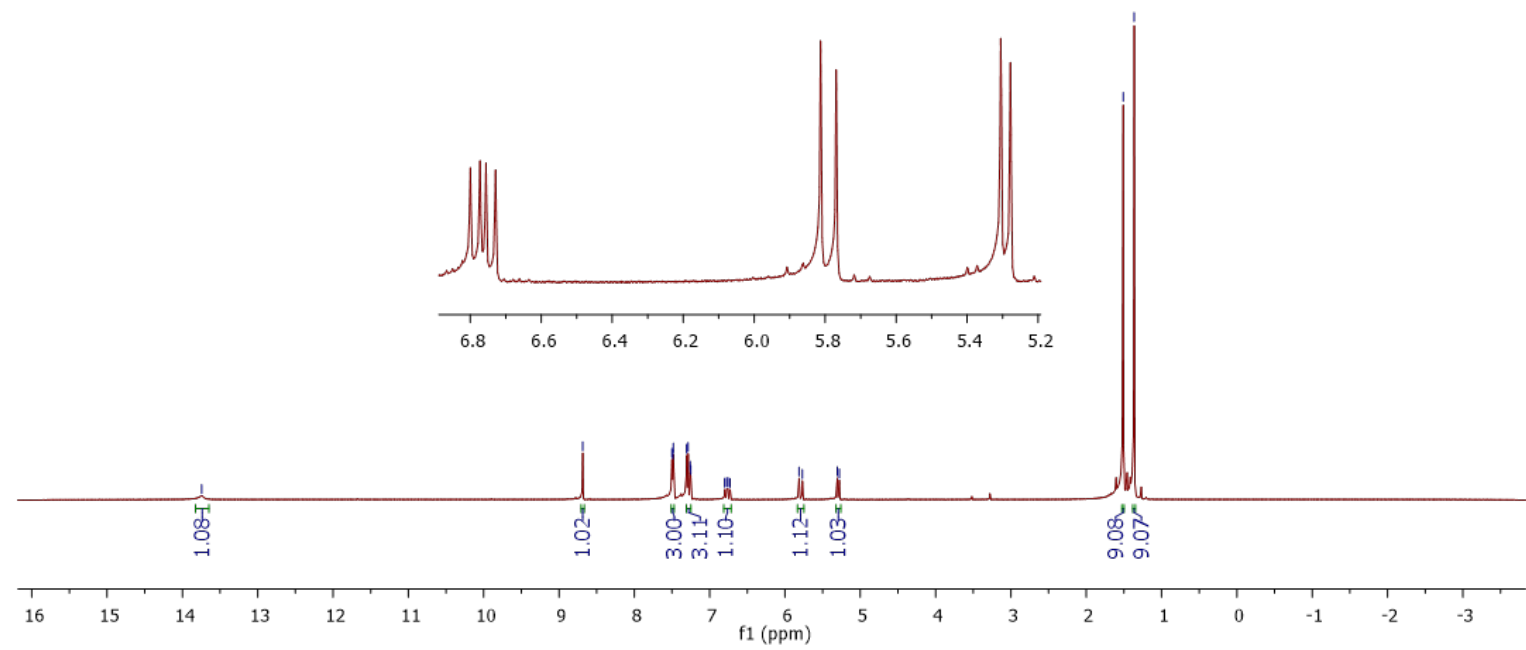

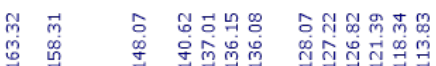

।

굴ำ

फें लं ले

11 ?

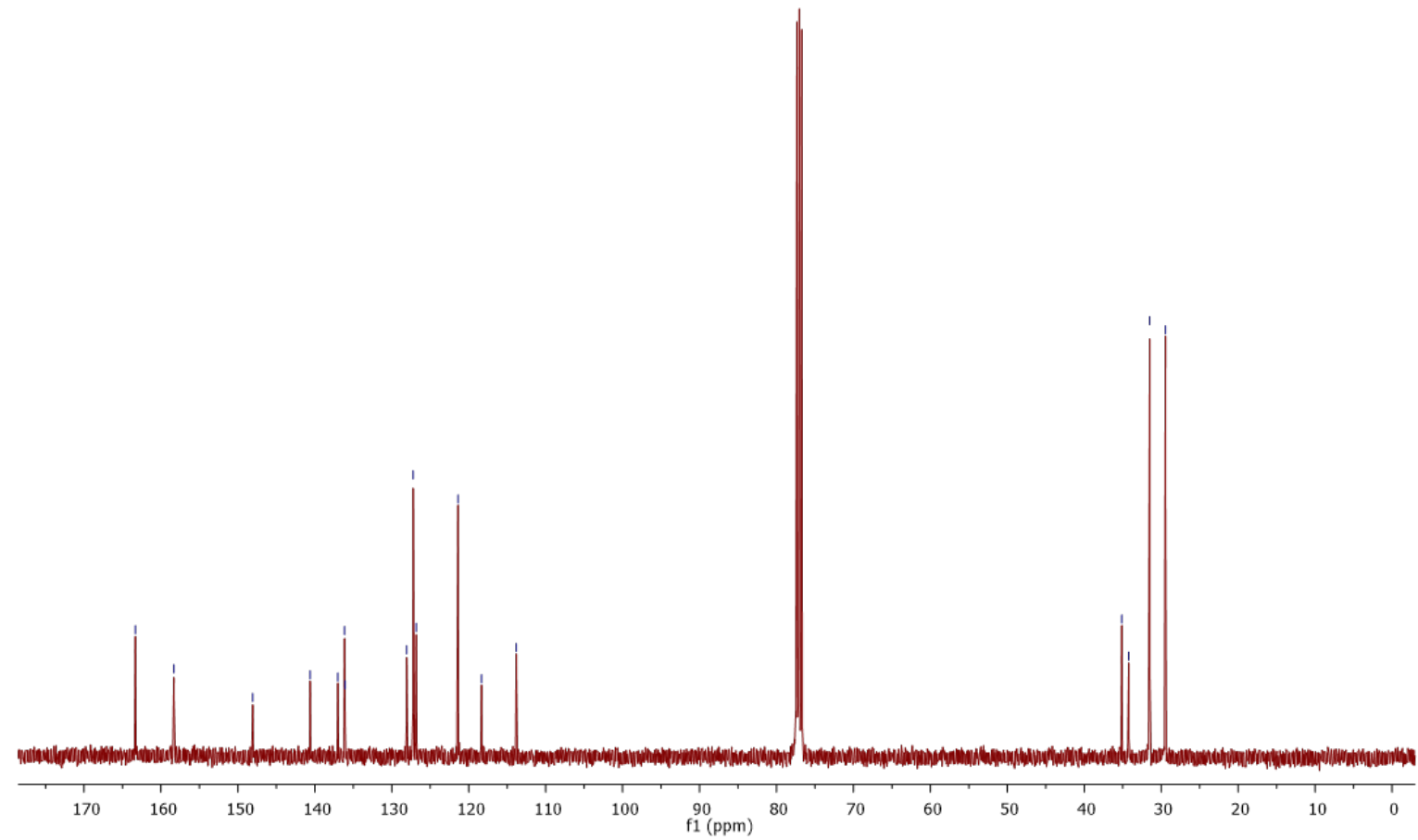

Figure 3. ${ }^{1} \mathrm{H}$ and $13 \mathrm{C} \mathrm{NMR} \mathrm{spectrum} \mathrm{of} \mathrm{compound} 5\left(\mathrm{CDCl}_{3}\right)$. 
In the ${ }^{13} \mathrm{C}$ NMR spectrum of compound 5 , aliphatic carbon atoms were observed in the range of $\delta$ 29.45-35.12 ppm, aromatic carbon atoms and vinyl carbons were observed in the range of $\delta 113.83 \mathrm{ppm}$ and $\delta 158.31$ ppm. The signal of the carbon atom in the imine bond resonated at $163.32 \mathrm{ppm}$. The ${ }^{1} \mathrm{H}\left({ }^{13} \mathrm{C}\right)$ NMR spectrum of compound 5 is given in Fig 3. FT-IR and ${ }^{1} \mathrm{H}\left({ }^{13} \mathrm{C}\right) \mathrm{NMR}$ analysis results of the compounds ( 4 and 5 ) confirm the proposed structures.

\section{Biological Activity Studies \\ AChE inhibition activity results}

The AChE inhibitions of salicylaldehyde-based compounds evaluated in this study are quite interesting. It has been observed that both compounds effectively inhibit AChE enzyme activity at micromolar level. It was determined that compound $4\left(\mathrm{IC}_{50}: 1.396 \pm 0.35\right)$ and compound $5\left(\mathrm{IC}_{50}: 0.795 \pm 0.47\right)$ effectively inhibited the AChE enzyme (Table 1). The acetylcholinesterase inhibitory effect of the compounds is given in Fig. 4. It was found that the inhibition activity of compound 5 , which has a di-t-butyl group, is more active than compound 4 , which has two chloride groups in its structure. It is thought that the activity difference is due to the alkyl groups in the structure. In addition, it was determined that tacrine (TAC), used as a standard AChE inhibitor in the study, had an $I_{50}$ value of $166.10 \pm 17.53 \mu \mathrm{M}$ against AChE. The AChE inhibition values of the synthesized compounds are dramaticaly higher than the TAC inhibition values, making them compounds that can be used as an alternative to TAC after evaluating the further pharmacologic properties of these compounds.

\section{Molecular Docking Results}

Molecular docking studies were performed using the AutoDock 4.2 program to determine the interaction mode, binding affinity and binding site of the most active inhibitor after in vitro experimental study of the compounds. First, acetylcholinesterase (AChE) cocrystallized ligand Galantamine (GNT) was removed and redocked to confirm the binding site. The fact that the redocked ligand was in close site proximity to the cocrystallized ligand confirmed the docking process (Fig 5). Confirmation of docking prosedure is useful for drugreceptor interactions.

Molecular docking study of compound 5 which is exprerimentally more active than compound 4 was performed. Compound 5 docking to the active site of AChE the best conformation binding affinity is $-10.17 \mathrm{kcal} / \mathrm{mol}$. The 3D docking pose of compound 5 is shown in Fig 6 . As a result of docking, the active site of AChE of compo-

Table 1. Determination of compound 4, compound 5 and standard Tacrin (TAC) AChE inhibition values.

\begin{tabular}{ccc}
\hline Comp. & AChE $(\mu \mathrm{M})$ & $\mathrm{R}^{2}$ \\
\hline 4 & $1.396 \pm 0.35$ & 0.9738 \\
\hline 5 & $0.795 \pm 0.47$ & 0.9906 \\
\hline TAC & $166.10[25]$ & 0.9665 \\
\hline
\end{tabular}
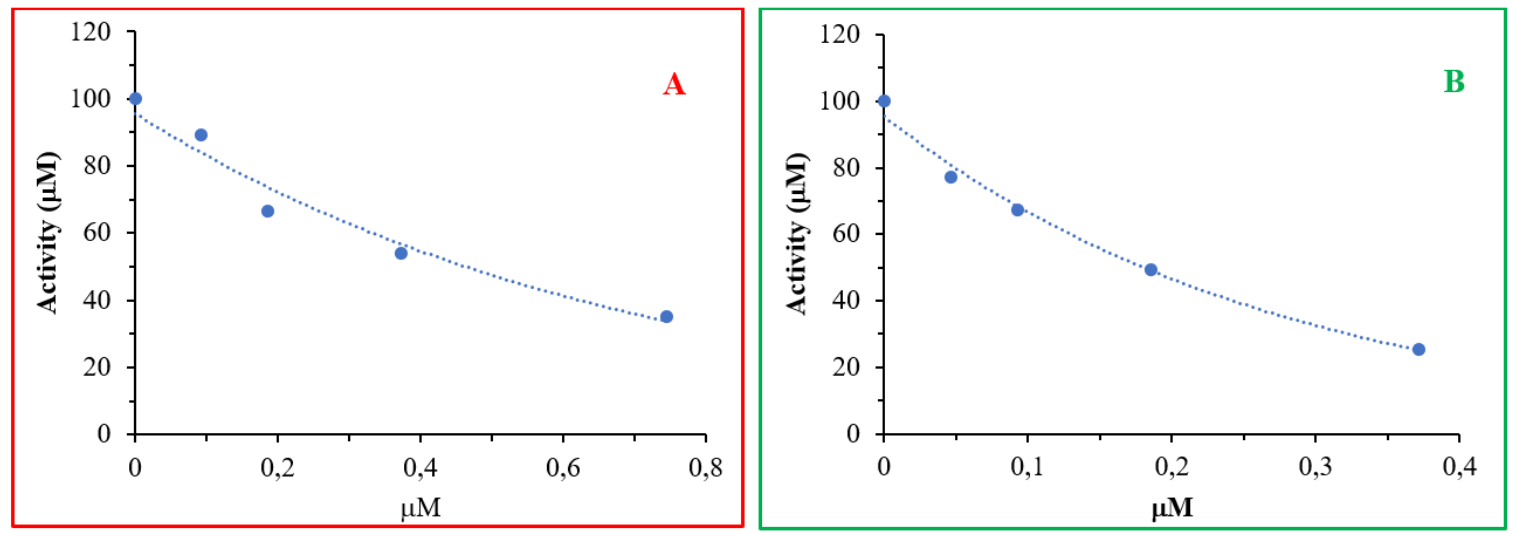

Figure 4. The effect of 4 and 5 compounds acetylcholinesterase (AChE) enzyme. A (for 4) and B (for 5 ) is IC50 values of schiff base compounds. 


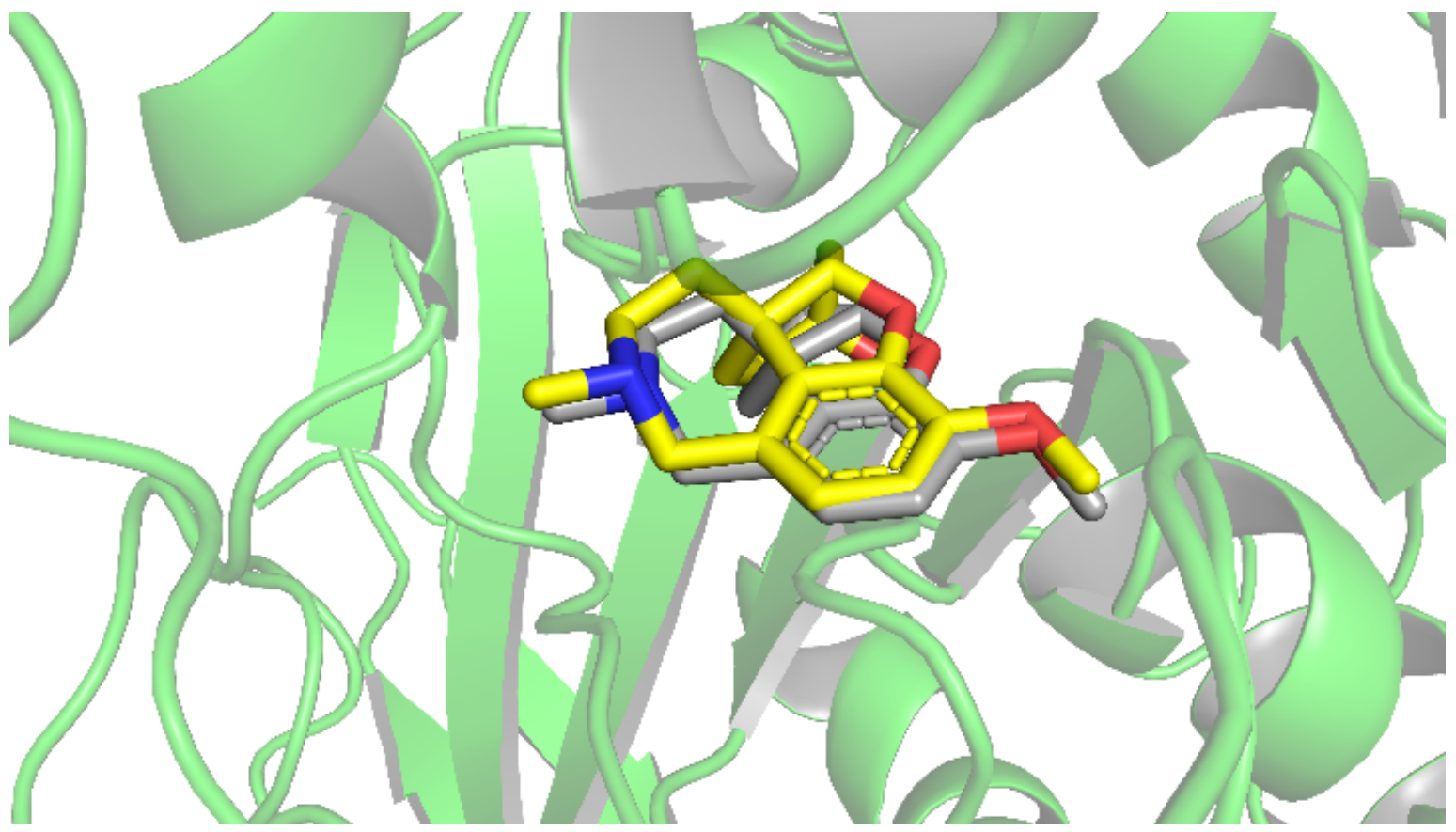

Figure 5. Redocked verification. AChE is shown in green in the stripe model. Poses of co-crystallized ligand are represented by balland-stick modeling in yellow, while poses of redocked ligands are represented by gray-colored ball-stick modeling.

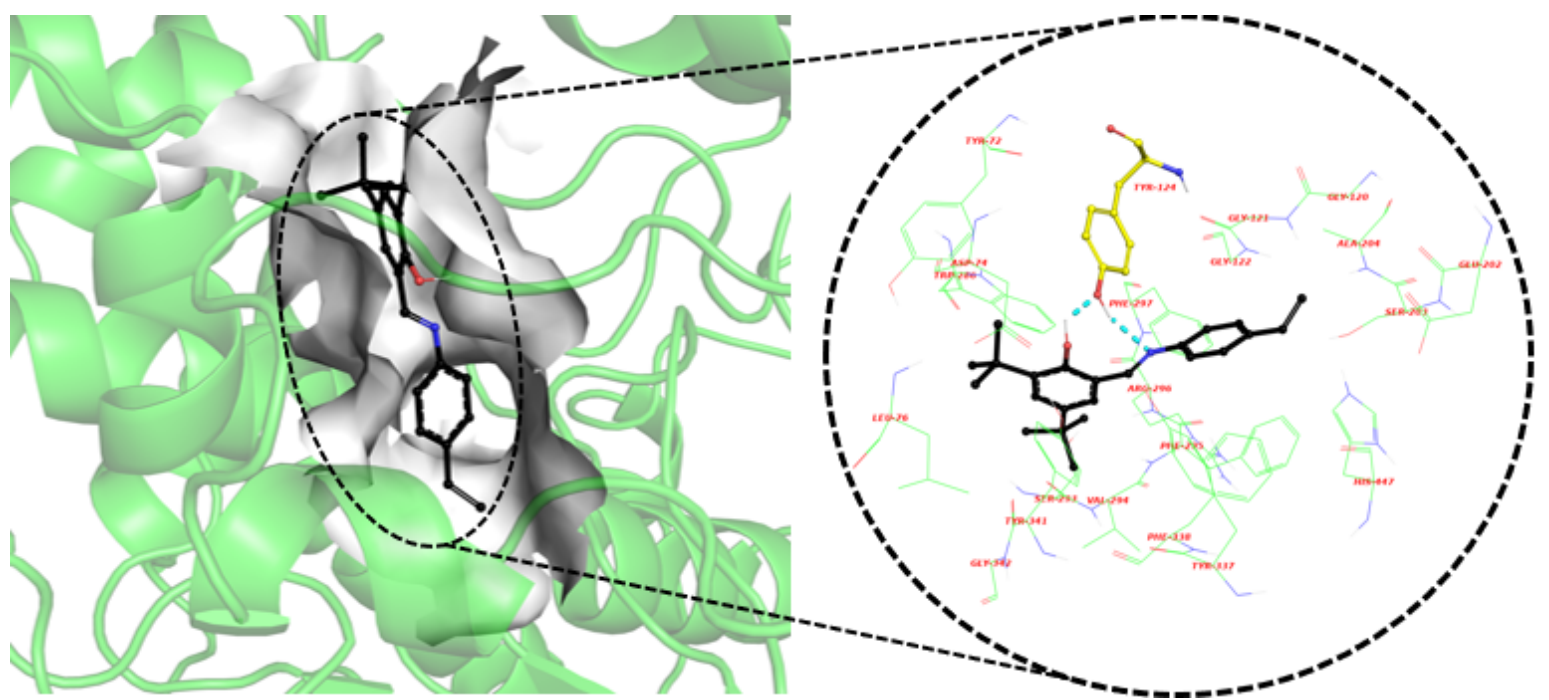

Figure 6. 3D pose of the lowest energy conformation of compound in the catalytic active site of the AChE (compound 5 is represented by a black colored ball stick modeling and the $\mathrm{H}$-bond turquoise dashed line). 


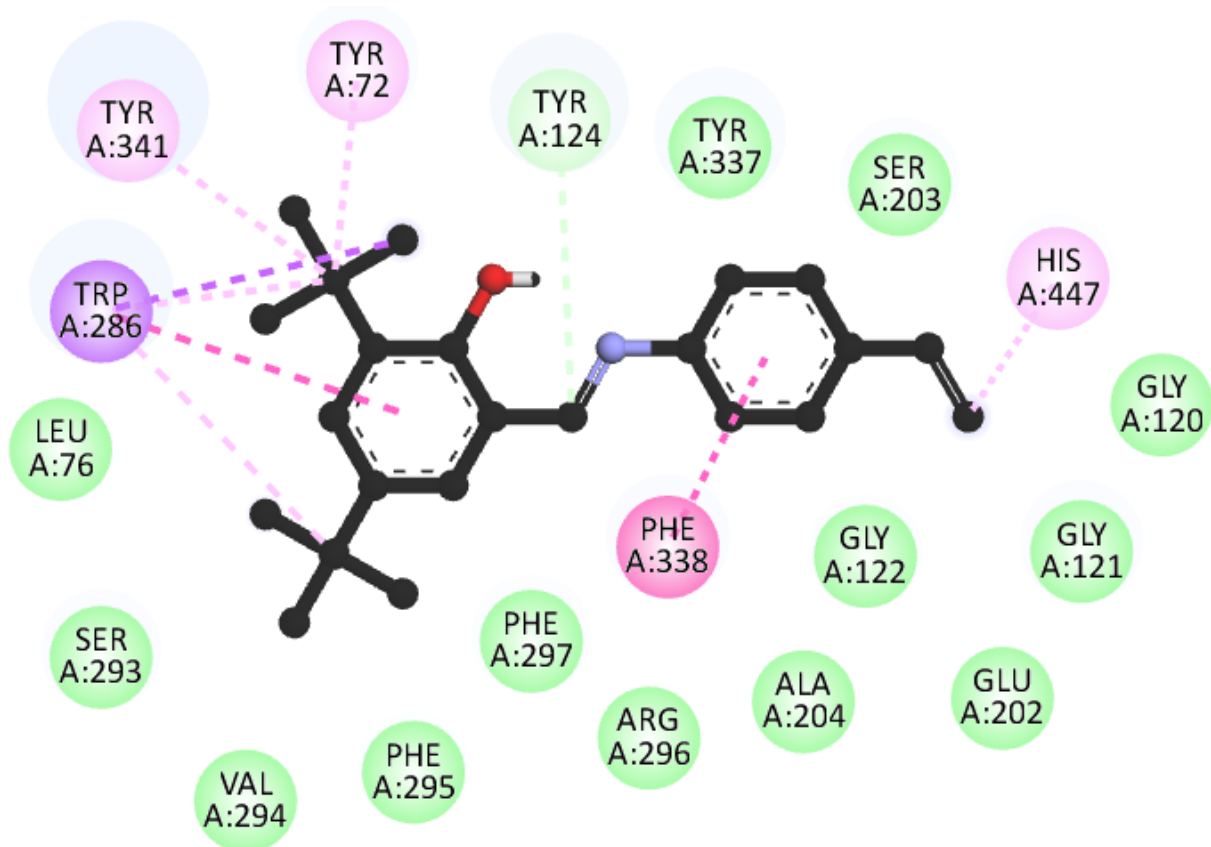

\section{Interactions}

Figure 7. $2 \mathrm{D}$ interaction profile of the lowest energy best conformation of compound 5 in the catalytic active site in AChE.

und 5 interacts with some amino acid residues. Compound $\mathbf{5}$ formed $\pi-\pi$ interaction with important amino acid residues in the peripheral anionic subregion (PAS) Trp286 ( $\pi-\pi$ interaction distances are $5.81 \AA$, $4.45 \AA$ ) and in the acyl binding pocket Phe338 (5.00 $\AA$ ). Compound 5 made two hydrogen bonds with $D \cdots \cdots \cdot$ A distances of (1.87 $\AA$ and $2.10 \AA$ ) with Tyr124 in the entrance region of the PAS area. Also compound $\mathbf{5}$ formed very hydrophobic interactions with residues in the active site of AChE (Fig 7). There are several subsites that can be distinguished in the active site of AChE: the esteratic subsite, also called the catalytic triad (Ser203, His447, Glu334), the oxyanion hole (Gly121, Gly122, Ala204), the anionic subsite (Trp86, Tyr133, Glu202, Gly448), Ile451), acyl binding pocket (Trp236, Phe295, Phe297, Phe338), peripheral anionic subregion (Asp74, Tyr72, Tyr124, Ser125, Trp286, Tyr337, Tyr341) [26-29].

\section{CONCLUSION}

In this study, two new Schiff base compounds based on salicylaldehyde were synthesized and their structures were characterized by spectroscopic methods. The compounds were then screaned for their AChE inhibition activities. The compounds (4 and $\mathbf{5}$ ) showed considerably higher AChE inhibition activity compared to the standard drug (Tacrin). The inhibitory activity of compounds $\mathbf{4}$ and $\mathbf{5}$ are comparable. Finally, molecular docking studies showed that compound $\mathbf{5}$ interacts with AChE via $\mathrm{H}$-bond and $\pi-\pi$ stacking interactions.

\section{Acknowledgments}

I would like to thank to Prof. Dr. Ferhan TÜMER for valuable help and interpreting the data. I would like to thank to Dr. Özge GÜNGÖR and Seyit Ali GÜNGÖR for biological activity and molecular docking studies. 


\section{References}

1. C.M. Da Silva et al., Schiff bases: A short review of their antimicrobial activities, J. Adv. Res., 2 (1) (2011) 1-8.

2. F.N. Ejiah et al., Substituent effect on spectral and antimicrobial activity of Schiff bases derived from aminobenzoic acids, Adv. Biol. Chem., 3 (05) (2013) 475-479

3. H.R. Afzal et al., Schiff Bases of Pioglitazone Provide Better Antidiabetic and Potent Antioxidant Effect in a Streptozotocin-Nicotinamide-Induced Diabetic Rodent Model, ACS Omega, 6 (2021) 4470-4479.

4. P. Przybylski et al., Biological Properties of Schiff Bases and Azo Derivatives of Phenols, Curr. Org. Chem., 13 (2009) 124 148.

5. F.S. Tokalı et al., Synthesis, characterization, biological activity and molecular docking studies of novel schiff bases derived from thiosemicarbazide: Biochemical and computational approach, J. Mol. Struct., 1231 (2021).

6. S. Onur et al., Synthesis, characterization and antibacterial effect of diarylmethylamine-based imines, J. Mol. Struct. 1214 (2020).

7. S. Onur et al., New imino-methoxy derivatives: design, synthesis, characterization, antimicrobial activity, DNA interaction and molecular docking studies, J. Biomol. Struct. Dyn., 0 (2021) 1-13.

8. G. Bringmann et al., Full Papers, 67 (2004) 5-10.

9. S. Afrin Dalia et al., A short review on chemistry of schiff base metal complexes and their catalytic application, 2859 Int. J. Chem. Stud., 6 (2018) 2859-2866.

10. C. Jang et al., Identification of novel acetylcholinesterase inhibitors designed by pharmacophore-based virtual screening, molecular docking and bioassay, Sci. Rep., 8 (1) (2018) 1-21.

11. E. Beal, Alzheimer disease:, Nat. Rev. Neurol., 7 (9) (2011) 474.

12. Alzheimer's Association, 2021 Alzheimer's disease facts and figures special report Race, Ethnicity and Alzheimer's in America, Alzheimers. Dement., 17 (2021) 327-406.

13. A. Rønneberg et al., The Editor recommends this issue's article to the reader, Int. J. Paediatr. Dent., 29 (2019) 683.

14. S. Duong, T. Patel, and F. Chang, Dementia: What pharmacists need to know, Can. Pharm. J., 150 (2) (2017) 118-129.

15. R.G. Jahn, Introduction, Role Conscious. Phys. World, (2019) 1-5.

16. H.R. Brunnström and E.M. Englund, Cause of death in patients with dementia disorders, Eur. J. Neurol., 16 (2009) 488-492.
17. J. Massoulié et al., Molecular and cellular biology of cholinesterases, Prog. Neurobiol., 41 (1993) 31-91.

18. M.S. More et al., Metal complexes driven from Schiff bases and semicarbazones for biomedical and allied applications: a review, Mater. Today Chem., 14 (2019) 100195.

19. P. Chandra Mohan and J. Venkateshwar Rao, Biological evaluation of Schiff bases of new Isatin derivatives for Anti Alzheimer's activity, Asian J. Pharm. Clin. Res., 7 (2014) 114117

20. J. Shi et al., Design, synthesis and biological evaluation of Schiff's base derivatives as multifunctional agents for the treatment of Alzheimer's disease, Med. Chem. Res., 30 (2021) 624-634

21. G. Ceyhan et al., Structural characterization, luminescence and electrochemical properties of the Schiff base ligands, J. Lumin., 132 (2012) 2917-2928.

22. G.L. Ellman et al., A new and rapid colorimetric determination of acetylcholinesterase activity, Biochem. Pharmacol., 7 (2) (1961) 88-95.

23. O. Gungor, M. Kose, and T.T. Tok, A biguanide derivative and its cyclic anologue: Structural chracterization, AChE inhibitory effect and docking studies, J. Mol. Struct., 1196 (2019) 491-498.

24. O. Gungor, S.N.K. Kurtar, and M. Kose, Water soluble biguanide salts and their 1,3,5-triazine derivatives as inhibitors of acetylcholinesterase and $\alpha$-glucosidase, Zeitschrift Fur Krist. - Cryst. Mater., 235 (2020) 465-475.

25. U. Atmaca et al., Novel hypervalent iodine catalyzed synthesis of $\alpha$-sulfonoxy ketones: Biological activity and molecular docking studies, J. Mol. Struct., 1239 (2021).

26. B.J. Bennion et al., A wrench in the works of human acetylcholinesterase: Soman induced conformational changes revealed by molecular dynamics simulations, PLoS One, 10 (2015) 1-31.

27. T. Mohamed et al., Selective inhibition of human acetylcholinesterase by xanthine derivatives: In vitro inhibition and molecular modeling investigations, Bioorganic Med. Chem. Lett., 23 (2013) 4336-4341.

28. Y. Pourshojaei et al., Phenoxyethyl Piperidine/Morpholine Derivatives as PAS and CAS Inhibitors of Cholinesterases: Insights for Future Drug Design, Sci. Rep., 9 (2019) 1-19.

29. B.L. De Sousa et al., Inhibition of acetylcholinesterase by coumarin-linked amino acids synthetized via triazole associated with molecule partition coefficient, J. Braz. Chem. Soc., 32 (2021) 652-664. 